\title{
Syntheses of Octaalkynylphthalocyanines from Halophthalonitriles $^{\dagger}$
}

\author{
CLIFFORD C. LEZNOFF", ZHAOPENG LI, HIROAKI ISAGO', ANNA M. D'ASCANIO and \\ DMITRI S. TEREKHOV
}

Department of Chemistry, York University, Toronto, Ontario M3J 1P3, Canada

\begin{abstract}
Coupling of 4,5-diiodophthalonitrile with tert-butyldimethylsilylacetylene and a palladium catalyst gave 4,5-bis(tert-butyldimethylsilylethynyl)phthalonitrile. Cleavage of the silyl moiety with tetrabutylammonium fluoride gave 4,5-diethynylphthalonitrile, while condensation in 2- $\mathrm{N}, \mathrm{N}$-dimethylaminoethanol without or with $\mathrm{Zn}(\mathrm{OAc})_{2}$ gave metal-free 2,3,8,9,16,17,23,24-octakis(tert-butyldimethylsilylethynyl)phthalocyanine or its zinc derivative. Cleavage of the silyl groups of the zinc derivative gave an insoluble product whose ${ }^{1} H$ NMR spectrum was indicative of $2,3,9,10,16,17,23,24-o c t a e t h y n y l p h$ thalocyaninato zinc(II). Bromination of phthalonitrile with $N, N$-dibromoisocyanuric acid gave a separable mixture of $3,6-, 3,4$ and 4,5-dibromophthalonitrile along with the monobromophthalonitriles. Coupling of 3,4-dibromophalonitrile with tert-butylacetylene gave 3,4-bis(tert-butylethynyl)phthalonitrile, which on condensation with lithium 1pentanolate gave 1,2,8,9,15,16,22,23-octakis(3,3-dimethyl-1-butynyl)phthalocyanine as a single isomer, the first known 1,2,8,9,15,16,22,23-octasubstituted phthalocyanine. Copyright $\mathbb{C} 1999$ John Wiley \& Sons, Ltd.
\end{abstract}

KEYWORDS: $1,2,8,9,15,16,22,23$-octakis(3,3-dimethyl-1-butynyl)phthalocyanine; 4,5-diethynylphthalonitrile; 3,4-bis(tert-butylethynyl)phthalonitrile; red shift absorption; dibromophthalonitrilés

\section{INTRODUCTION}

Octasubstituted phthalocyanines are well known [1] and have been studied for applications [1] in a wide variety of areas, including dyes [2], chemical sensors [3], non-linear optics [4] and photodynamic therapy of cancer [5,6]. Recently, hexaalkynylbenzenes [7] and alkynylporphyrins [8] have been described as possible compounds for use in non-linear optics and arrays [8,9]. With this in mind a series of $2,3,9,10,16,17,23,24$-octaalkynylphthalocyanines were prepared [10] and their ${ }^{1} \mathrm{H}$ NMR spectra studied with respect to their variation in chemical shifts with concentration and temperature. Alkynyl-substituted phthalocyanines are fairly rare [10-15], but are

*Correspondence to: C. C. Leznoff, Department of Chemistry, York University, Toronto, Ontario M3J 1P3, Canada.

†Visiting scholar from National Research Institute for Metals, 1-21, Sengen, Tsukuba, Ibaraki 305, Japan.

Paper presented at 2nd International Symposium on Phthalocyanines, Edinburgh, September 1998. particularly interesting in that each alkynyl group causes a red shift of $4-6 \mathrm{~nm}$ at $700 \mathrm{~nm}$ and hence polyalkynyl-substituted phthalocyanines can be prepared and selected for exact absorption maxima depending on the number of alkyne groups present and whether, of course, the phthalocyanine $(\mathrm{Pc})$ is metallated or not. In this paper some silyl-protected $2,3,9,10,16,17,23,24$-octaalkynylphthalocyanines will be described and their cleavage reactions studied. An unusual $1,2,8,9,15,16,22,23$-octasubstituted phthalocyanine, the first Pc with this substitution pattern, is outlined.

\section{RESULTS AND DISCUSSION}

Coupling of 4,5-diiodophthalonitrile (1) [10] with commercially available (Fluka) tert-butyldimethylsilylacetylene (2) using $\mathrm{Pd}\left(\mathrm{PPh}_{3}\right)_{2} \mathrm{Cl}_{2}$ and $\mathrm{CuI}$ as catalysts [16-18] in triethylamine (TEA) at room temperature gave 4,5-bis(tert-butyldimethylsilylethynyl)phthalonitrile (3) in $90 \%$ yield. Removal of the tertbutyldimethylsilyl (TBDS) groups of 3 could be readily achieved using tetrabutylammonium fluoride 
<smiles>N#Cc1cc(I)c(I)cc1C#N</smiles>

1<smiles>[R]C#Cc1cc(C#N)c(C#N)cc1C#N</smiles>

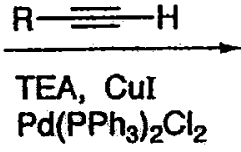

$2 \mathrm{R}=\left(\mathrm{CH}_{3}\right)_{3} \mathrm{C}\left(\mathrm{CH}_{3}\right)_{2} \mathrm{Si}$<smiles>C#Cc1cc(C#C)c(C#N)cc1C#N</smiles>

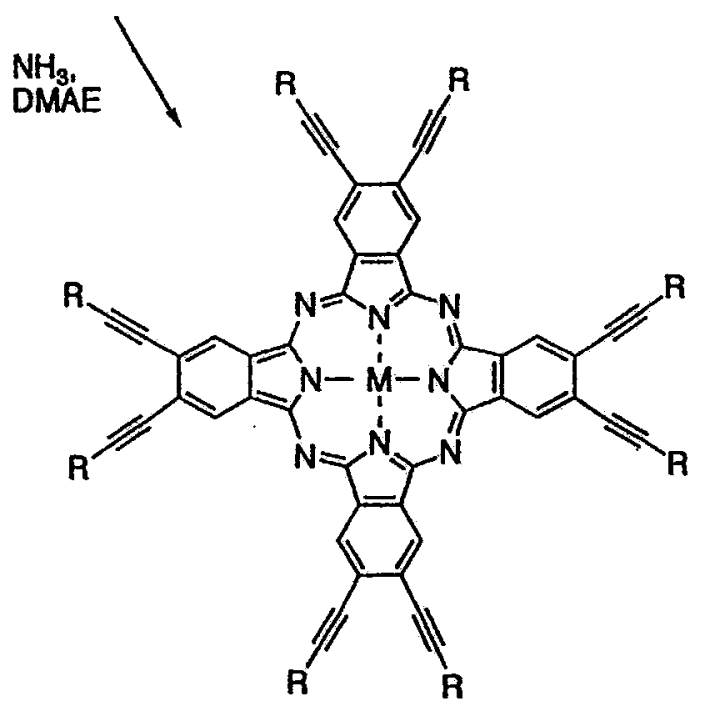

$$
\begin{aligned}
& 5 \mathrm{M}=\mathrm{H}_{2}, \mathrm{R}=\left(\mathrm{CH}_{3}\right)_{3} \mathrm{C}\left(\mathrm{CH}_{3}\right)_{2} \mathrm{Si} \\
& 6 \mathrm{M}=\mathrm{Zn}, \mathrm{R}=\left(\mathrm{CH}_{3}\right)_{3} \mathrm{C}\left(\mathrm{CH}_{3}\right)_{2} \mathrm{Si} \\
& 7 \mathrm{M}=\mathrm{H}_{2}, \mathrm{R}=\mathrm{H} \\
& 8 \mathrm{M}=\mathrm{Zn}, \mathrm{R}=\mathrm{H}
\end{aligned}
$$

Scheme 1.

(TBAF) to give 4,5-bis(ethynyl)phthalonitrile (4) in $73 \%$ yield. Slow heating of 4 on a melting point apparatus showed no m.p. below $300^{\circ} \mathrm{C}$, but the addition of a crystal on a hot Kofler block exhibited a sharp decomposition point at $135^{\circ} \mathrm{C}$. It is known that direct condensation of an alkynylphthalonitrile does not give phthalocyanines $[10,11,15]$ and hence the silyl-protected phthalonitrile 3 was used in the condensation step to phthalocyanines. Many variations of phthalocyanine syntheses are known [1,2], but most use strong base or high temperatures to achieve $\mathrm{Pc}$ formation. In the event, treatment of 3 in 2 $N, N$-dimethylaminoethanol (DMAE) at $110^{\circ} \mathrm{C}$ with continuous bubbling of ammonia gas $[11,19]$ gave 
<smiles>N#Cc1ccccc1C#N</smiles>

9<smiles>N#Cc1c(Br)ccc(Br)c1C#N</smiles>

12<smiles>N#Cc1cccc(Br)c1C#N</smiles>

10<smiles>N#Cc1ccc(Br)c(Br)c1C#N</smiles>

13<smiles>N#Cc1ccc(Br)cc1C#N</smiles>

11<smiles>N#Cc1cc(Br)c(Br)cc1C#N</smiles>

14

Scheme 2.

the desired $2,3,9,10,16,17,23,24$-octakis(tertbutyldimethylsilylethynyl)phthalocyanine (5) in $25 \%$ yield. Alternatively, treatment of $\mathbf{3}$ as above gave a solution which reacted with dry zinc acetate in $N, N$-dimethylformamide (DMF) and toluene to give 2,3,9,10,16,17,23,24-octakis(tert-butyldimethylsilylethynyl)phthalocyaninato zinc(II) (6) in $24 \%$ yield. Cleavage of 5 and 6 with TBAF in THF was attempted and in both cases extremely insoluble blue material was isolated, which is suggested to be $2,3,9,10,16$, $17,23,24$-octakis(ethynyl)phthalocyanine (7) and 2,3, $9,10,16,17,23,24$-octakis(ethynyl)phthalocyaninato zinc(II) (8) respectively (Scheme 1). Both 7 and 8 proved to be too insoluble to purify to give satisfactory elemental analysis or even EI or FAB mass spectra. Compound 8 was very slightly soluble in hot pyridine$\mathrm{d}_{5}$ to give the expected ${ }^{1} \mathrm{H}$ NMR spectrum with singlets at 9.82 and $4.47 \mathrm{ppm}$ representing the aromatic and ethynyl protons (cf. the absorption of the ethynyl protons of 4 at $3.70 \mathrm{ppm}$ ). It is important to use the bulky tert-butyldimethylsilyl group as the ethynyl-blocking group, as preliminary work using the trimethylsilyl group gave unsatisfactory results.

Bromination of aromatic compounds containing electron-withdrawing substitutions is difficult $[20,21]$, but proceeds under milder conditions using $N, N$ dibromoisocyanuric acid (DBI) [22]. Thus DBI was dissolved in $8 \%$ fuming sulfuric acid in an ice bath and reacted with phthalonitrile (9) in a $1: 2$ ratio for 5 $20 \mathrm{~min}$. The crude product contained a mixture of unreacted 9, monobrominated $(\mathbf{1 0 , 1 1})$, dibrominated (12-14) and traces of higher-brominated phthalonitriles as shown by mass spectroscopy (Scheme 2). The reaction mixture was separated by flash chromatography on silica gel using a gradient of ethyl acetate/ hexane as eluent. Separation by this method proved to be somewhat difficult owing to the fact that the compounds had very close retention times. Small fractions were collected and separation was monitored using thin layer chromatography (TLC). Some of the fractions contained a mixture of products and had to be rechromatographed using similar conditions. Partial recrystallization was involved in this separation, because some of the compounds were much less soluble than others. The compounds obtained were characterized by elemental analysis, ${ }^{1} \mathrm{H}$ NMR spectroscopy and mass spectroscopy (MS).

${ }^{1} \mathrm{H}$ NMR spectroscopy and MS were also used to distinguish which of the dibromophthalonitriles were present in the various fractions. The fraction that contained pure 3,4-dibromophthalonitrile (13) was identified by the presence of two doublets at 7.8 and $8.0 \mathrm{ppm}$ respectively. Both 3,6-dibromophthalonitrile (12) and 4,5-dibromophthalonitrile (14) are symmetrical and contain two hydrogens, which are chemically equivalent, and thus both display only a singlet in their respective ${ }^{1} \mathrm{H}$ NMR spectra. In the case of 14 the hydrogens are adjacent to two electron-withdrawing groups (nitrile and bromine), while in the case of $\mathbf{1 2}$ they are only adjacent to one bromine group. As a result of this, the singlet corresponding to the hydrogens of 14 appeared more downfield than that corresponding to 12 . Thus compound 14 displayed a singlet at $8.0 \mathrm{ppm}$, while compound 12 displayed a singlet at $7.7 \mathrm{ppm}$. In any event, 14 was synthesized by an alternative route (see below). 
<smiles>N#Cc1cccc([N+](=O)[O-])c1C#N</smiles>

15 15

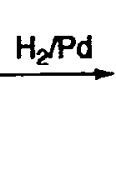

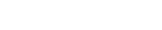<smiles>N#Cc1cccc(N)c1C#N</smiles>

16<smiles>N#Cc1cc([N+](=O)[O-])cc([N+](=O)[O-])c1Br</smiles>

Scheme 3.
Isolation of compounds 12 and 13 indicated to us that both 3-bromophthalonitrile (10) and 4-bromophthalonitrile (11) are formed during the bromination reactions. However, at first, only 11 was isolated as a pure compound. The ${ }^{1} \mathrm{H}$ NMR spectrum of 11 contained three signals: a singlet at $8.1 \mathrm{ppm}$ for the proton at $\mathrm{C}_{3}$ with a small splitting from the meta coupling with the proton at $\mathrm{C}_{5}$, a doublet at $7.9 \mathrm{ppm}$ (proton at $\mathrm{C}_{6}$ ) and a doublet at $7.7 \mathrm{ppm}$ with a small splitting from the meta coupling with the $\mathrm{C}_{3}$ proton which corresponded to the proton at $\mathrm{C}_{5}$ of 4 bromophthalonitrile (11). The isolation of 10 was much more difficult because of the similarity of its retention time to that of the starting material 9. Compound 10 was thus synthesized independently from 3-nitrophthalonitrile 15 (Scheme 3).

Dibromophthalonitriles 12-14 were synthesized for the first time. Although these compounds were produced in yields below $10 \%$, for the 3,6- and $3,4-$ dibromophthalonitriles (12 and 13) it is the only available method for their synthesis. It is especially important for phthalonitrile 13, because it is one of the few 3,4-derivatives of phthalonitrile that have been prepared. Many 3,6-derivatives of phthalonitrile are known $[23,24]$, but the use of 12 as the starting material in substitution reactions can provide a much wider variety of 3,6-disubstituted phthalonitriles.

Catalytic hydrogenation of 3-nitrophthalonitrile (15) gave 3-aminophthalonitrile [25] (16). 3-Bromophthalonitrile (10) was synthesized by the conventional Sandmeyer reaction. This procedure involved a conversion of 16 to its diazonium salt and the addition of this salt to a cold solution of cuprous bromide [26]. The crude product of the Sandmeyer reaction was purified by silica gel column chromatography and recrystallized from benzene/hexane to give 10 in $45 \%$ yield (Scheme 3 ). The ${ }^{1} H$ NMR spectrum of 10 consists of three signals. The doublet at $7.9 \mathrm{ppm}$ corresponds to the hydrogen at the 6-position because of the effect of the adjacent cyano group, the doublet at $7.8 \mathrm{ppm}$ corresponds to the hydrogen at the 4-position and the triplet at $7.6 \mathrm{ppm}$ belongs to the hydrogen at the 5-position. The mass spectrum of compound 10 shows the molecular ion as a doublet with equal intensities, consistent with the isotopic ratios for bromine-containing molecules.

The successful synthesis of 4,5-diiodophthalonitrile from phthalimide (17) led us to prepare 14 using the<smiles>O=C1NC(=O)c2ccccc21</smiles>

17<smiles>O=C1NC(=O)c2cc(Br)c(Br)cc21</smiles>

$18 a$<smiles>O=C(O)c1cc(Br)c(Br)cc1C(=O)O</smiles>

$18 b$<smiles>NC(O)O</smiles><smiles>NC(=O)c1cc(Br)c(Br)cc1C(N)=O</smiles>

19

Scheme 4. 
<smiles>N#Cc1ccc(Br)c(Br)c1C#N</smiles>

13<smiles>CC#Cc1ccc(C#N)c(C#N)c1Br</smiles>

21

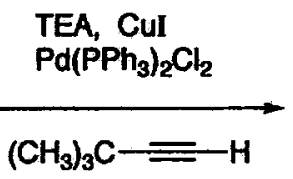

20<smiles>CC#Cc1ccc(C#N)c(C#N)c1C#CC</smiles>

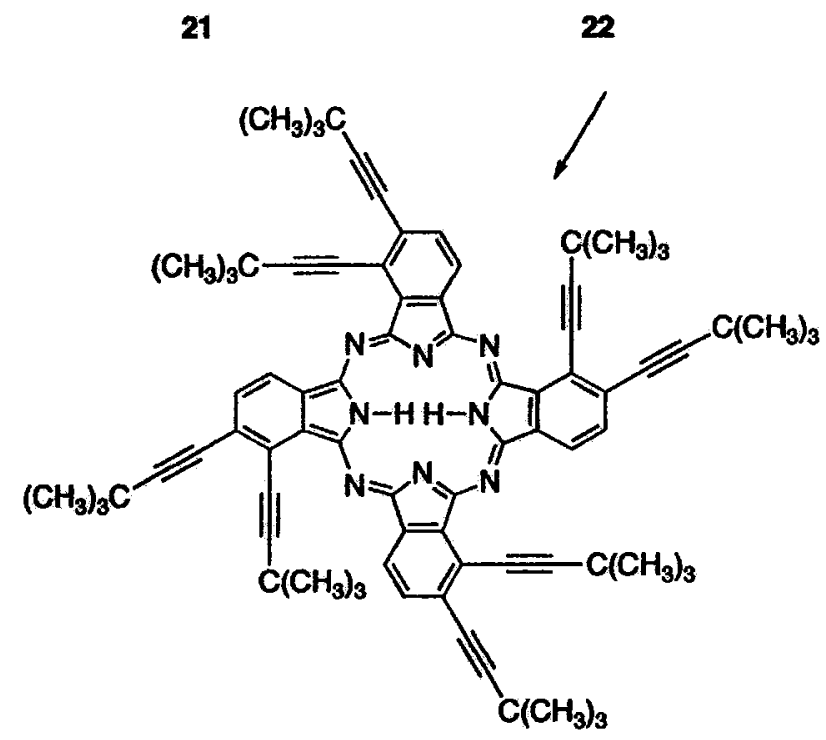

23

Scheme 5.

same route. The treatment of phthalic anhydride with two equivalents of bromine leads to a mixture, as would be anticipated. The principal product is said to be the 4,5-dibromophthalic anhydride [27], but in one instance [28] it is recorded that only 3,4-dibromophthalic acid was secured. We decided to use $33 \%$ instead of $60 \%$ fuming sulfuric acid and reduce the temperature of the reaction to $60^{\circ} \mathrm{C}$. A small amount of iodine was used as a catalyst for the bromination reaction. We were able to isolate only two products of the reaction, 4,5-dibromophthalimide (18a) and 4,5-dibromophthalic acid (18b), the product of hydrolysis of 18a. No 3,4-isomer was found, as in the case of iodination of phthalimide.

The conversion of $18 \mathrm{a}$ to 14 was carried out in two steps. First, 4,5-dibromophthalamide (19) was synthesized by treatment of phthalimide $18 \mathrm{a}$ with concentrated aqueous ammonium hydroxide solution at $40^{\circ} \mathrm{C}$. Phthalamide 19 was dehydrated with trifluoroacetic anhydride in dioxane/pyridine and recrystal- 


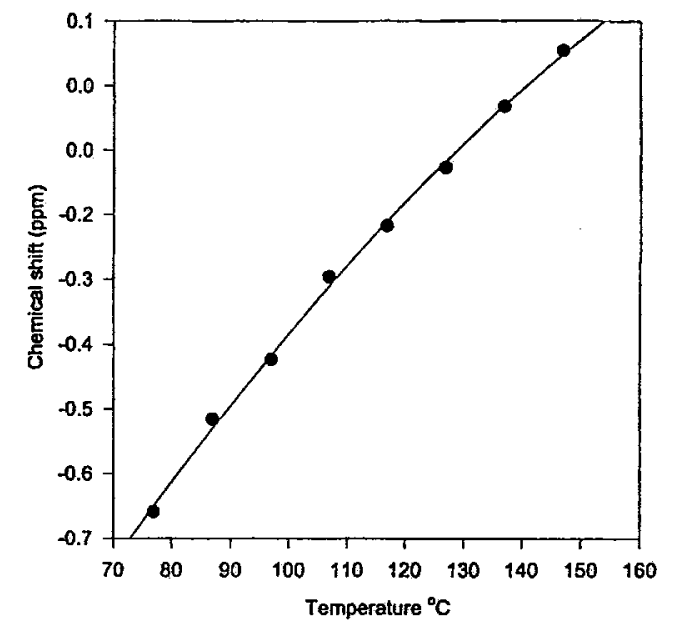

Fig. 1. Temperature dependence of chemical shift of internal protons of 23 in nitrobenzene- $d_{5}\left(1 \times 10^{-4} \mathrm{M}\right)$.

lized from ethanol to give pure 14 in $85 \%$ yield using a known procedure [29]. The synthesis of 14 from 17 is outlined in Scheme 4.

The advantages of using 14 instead of 4,5diiodophthalonitrile for future syntheses are its decreased light sensitivity and less facile degree of debromination in comparison with deiodination in reactions catalyzed by transition metals [30]. The reactivities of 14 and 4,5-diiodophthalonitrile are similar in coupling reactions.

Finally, the desired 3,4-dibromophthalonitrile (13) reacted with tert-butylacetylene $\mathbf{2 0}$, as for the preparation of 3, to give 3-bromo-4-(3,3-dimethyl-1butynyl)phthalonitrile (21) and 3,4-bis(3,3-dimethyl1-butynyl)phthalonitrile (22) in $45 \%$ and $40 \%$ yields respectively. Using large excesses of catalyst or 20 did not lead to increases in the yield of 22 . In addition, the use of 3;4-diiodophthalonitrile [10] gave the desired product (22), but mixed with 3-iodo-4-(3,3-dimethyl1-butynyl)phthalonitrile and 4-(3,3-dimethyl-1-butynyl)phthalonitrile (a deiodinated product), and this mixture proved difficult to separate. It appears that bromoaromatic compounds are less prone than iodoaromatic compounds to dehalogenation reactions with palladium catalysts [30]. Finally, condensation of 22 with lithium 1-pentanolate in 1-pentanol at $110^{\circ} \mathrm{C}$ (not $135^{\circ} \mathrm{C}$ ) gave $1,2,8,9,15,16,22-23$-octakis $(3,3-$ dimethyl-1-butynyl)phthalocyanine (23) in 35\% yield (Scheme 5) as a single isomer. It is now well known $[31,32]$ that bulky substituents at the 3-position of a phthalonitrile can direct the tetracyclization so that only one isomer of a tetrasubstituted phthalocyanine is produced.

The ${ }^{1} \mathrm{H}$ NMR spectra of 5 and 6 were unusual in that their chemical shifts did not vary with concentration as was shown with similar octaalkynylphthalocyanines [10]. Obviously, the tert-butyldimethylsilyl groups are sufficiently bulky to inhibit aggregation between the phthalocyanine rings of two molecules. The ${ }^{1} H$ NMR spectrum of 23 confirmed the identity of 23 as a single isomer (see Experimental), but since 23 exhibited a maximum solubility of $10^{-4} \mathrm{M}$, concentration studies were not feasible. Still, ${ }^{1} \mathrm{H}$ NMR spectra of 23 at temperatures varying from 80 to $150^{\circ} \mathrm{C}$ exhibited a variation of the internal proton by $0.7 \mathrm{ppm}$ (Fig. 1). The UV-vis spectra of 5 and 23 are very similar despite their difference in isomeric positions, both exhibiting the expected red shift of 4-6 nm per alkyne group at $700 \mathrm{~nm}$. This is actually unusual, as it is well known that substitution at the $1,4,8,11,15,18,22,25$ positions of phthalocyanines causes red shifts in their UV-vis spectra $[1,23,24]$. Suggested terminal alkynes $(7,8)$ exhibit substantially less UV-vis shifts, as is consistent with a recently reported terminal tetralkynylphthalocyanine [15].

\section{EXPERIMENTAL}

All organic solvents were dried by appropriate methods and distilled before use. All reagents were freshly distilled or were recrystallized and then dried under reduced pressure before use. Zinc acetate $\left(\mathrm{Zn}(\mathrm{AcO})_{2} \cdot 2 \mathrm{H}_{2} \mathrm{O}\right)$ was finely ground, dried at $110^{\circ} \mathrm{C}$ under vacuum for $36 \mathrm{~h}$ and then stored in sealed vials. Unless otherwise noted, Praxair high-purity argon was used to maintain inert atmosphere conditions, and magnetic stirring methods were utilized during distillation and reaction processes. Thin layer chromatography (TLC) was performed using silica gel $G$ as the stationary phase. Flash chromatography was performed using silica gel of particle size $20-45 \mu \mathrm{m}$. Melting points (m.p.) were determined using a Kofler hot stage melting point apparatus and are uncorrected. IR spectra were recorded on a Pye Unicam SP3-200 or a Perkin-Elmer infrared spectrophotometer, and FT-IR was performed on a Unicam Mattson 3000 FT-IR spectrometer using $\mathrm{KBr}$ disks. UV-vis spectra were recorded on a Hewlett-Packard HP8451A diode array spectrophotometer. Mass spectra were obtained by $\mathrm{Dr}$ B. Khouw (York University, Toronto, Ontario, Canada) and recorded at $70 \mathrm{eV}$ on a Kratos MS-50 
triple-analyzer mass spectrometer in the EI mode. FAB mass spectra were obtained with a Kratos MS-50 triple-analyzer mass spectrometer equipped with a FAB ion source of standard Kratos design and an Ion Tech atom gun. Microanalyses were performed by Guelph Chemical Laboratories Ltd, Guelph, Ontario. Nuclear magnetic resonance ( ${ }^{1} \mathrm{H}$ NMR) spectra for protons and carbons were recorded on a Bruker ARX 400 high-field Fourier transform instrument. ${ }^{13} \mathrm{C}$ NMR resonances are reported as the protondecoupled chemical shifts, and in most cases the JMOD or/and DEPT ${ }^{13} \mathrm{C}$ NMR technique was used to differentiate carbons.

\section{4,5-Bis(tert-butyldimethylsilylethyl)phthalonitrile (3)}

To a $100 \mathrm{~mL}$ round-bottom flask placed in an ice$\mathrm{NaCl}$ bath were added 4,5-diiodophthalonitrile (1) $(1.0 \mathrm{~g}, 2.6 \mathrm{mmol})$ [8], bis(triphenylphosphine)palladium(II) chloride $(65 \mathrm{mg})$, copper(I) iodide $(800 \mathrm{mg}$, $4.21 \mathrm{mmol})$ and triethylamine $(60 \mathrm{~mL})$ under Ar. At $0^{\circ} \mathrm{C}$, tert-butyldimethylsilylacetylene (2) $(1.0 \mathrm{~g}$, $7.14 \mathrm{mmol}$ ) was added via a syringe within $20 \mathrm{~min}$. The reaction mixture was stirred at $0^{\circ} \mathrm{C}$ for $30 \mathrm{~min}$ and then at room temperature for $14 \mathrm{~h}$. As the reaction proceeded, a dark brown precipitate was formed. The precipitate was filtrated and washed with ethyl acetate (200 mL), After evaporation of the solvents the crude product was purified by flash column chromatography using $40 \%$ dichloromethane-petroleum ether (30$60^{\circ} \mathrm{C}$ ) as eluent. A pale yellow crystalline product was obtained $(950 \mathrm{mg}, 90 \%)$, m.p. $149-151^{\circ} \mathrm{C}$. IR $\left(\mathrm{KBr}, \mathrm{cm}^{-1}\right): 2233(\mathrm{C} \equiv \mathrm{N}, \mathrm{s}), 2156(\mathrm{C} \equiv \mathrm{C}, \mathrm{w})$. UVvis (THF) (nm, relative intensity): $262(1.57), 310$ (0.52). ${ }^{1} \mathrm{H} \mathrm{NMR}\left(\mathrm{CDCl}_{3}\right): \delta 7.83(\mathrm{~s}, 2 \mathrm{H}), 1.00(\mathrm{~s}, 18 \mathrm{H})$, $0.21(\mathrm{~s}, 12 \mathrm{H}) .{ }^{13} \mathrm{C}$ NMR: $\delta 137.4,130.6,114.5,114.2$, $105.9,100.4,26.16,16.73,0.02$. MS $(\mathrm{m} / \mathrm{z}$, relative intensity): $404\left(\mathrm{M}^{+}, 40\right), 347\left(\mathrm{M}^{+}\right.$-butyl, 100). Anal. calc. for $\mathrm{C}_{24} \mathrm{H}_{32} \mathrm{~N}_{2} \mathrm{Si}_{2}$ : C, 71.29; $\mathrm{H}, 7.92 ; \mathrm{N}, 6.93$. Found: $\mathrm{C}, 71.36 ; \mathrm{H}, 8.12 ; \mathrm{N}, 6.81$.

\section{4,5-Bis(ethynyl)phthalonitrile (4)}

Compound 3 (100 $\mathrm{mg}, 0.248 \mathrm{mmol})$ was dissolved in THF $(10 \mathrm{~mL})$. Five drops of water and two drops of TBAF (1.0 M solution in THF) were added. The reaction mixture turned black immediately. After stirring at room temperature for $30 \mathrm{~min}$, the reaction mixture was diluted with ethyl acetate $(10 \mathrm{~mL})$ and washed with water $(10 \mathrm{~mL} \times 3)$. The combined organic solution was dried over $\mathrm{MgSO}_{4}$. The crude product was dissolved in dichloromethane (ca $5 \mathrm{~mL}$ ) and purified by flash column chromatography using $20 \%$ ethyl acetate/hexanes as eluent. A pale yellow crystalline product was obtained ( $32 \mathrm{mg}, 73 \%)$, m.p. $135^{\circ} \mathrm{C}$ (decomp). IR (KBr, cm $\left.{ }^{-1}\right): 3315(\mathrm{C} \equiv \mathrm{CH}, \mathrm{s})$, $2239(\mathrm{C} \equiv \mathrm{N}, \mathrm{s}), 2108(\mathrm{C} \equiv \mathrm{C}, \mathrm{s}) .{ }^{1} \mathrm{H}$ NMR $\left(\mathrm{CDCl}_{3}\right): \delta$ $7.91(\mathrm{~s}, 2 \mathrm{H}), 3.70(\mathrm{~s}, 2 \mathrm{H}) .{ }^{13} \mathrm{C} \mathrm{NMR}\left(\mathrm{CDCl}_{3}\right): \delta 7.91$ $(\mathrm{s}, 2 \mathrm{H}), 3.70(\mathrm{~s}, 2 \mathrm{H}) .{ }^{13} \mathrm{C}$ NMR $\left(\mathrm{CDCl}_{3}\right): \delta 137.0$, $130.4,115.2,114.2,88.17,78.63$. MS $(\mathrm{m} / z$, relative intensity): $176\left(\mathrm{M}^{+}, 100\right), 149(52)$. Anal. calc. for $\mathrm{C}_{12} \mathrm{H}_{4} \mathrm{~N}_{2}$ : C, 81.82; H, 2.27; N, 15.91. Found: C, 81.40; H, 2.02; N, 15.44 .

\section{2,3,9,10,16,17,23,24-Octakis(tert-} butyldimethylsilylethynyl)phthalocyanine (5)

Compound 3 (100 mg, $0.25 \mathrm{mmol}$ ) was dissolved in 2$N, N$-dimethylaminoethanol (DMAE) (1 mL). As ammonia gas was bubbled through, the reaction mixture was heated to $100-110^{\circ} \mathrm{C}$ (sand bath) and kept for $1 \mathrm{~h}$. During this period the initial light orange color turned to dark orange. When heated to refiux, the color of the reaction mixture became green. After refluxing for $4 \mathrm{~h}$, the reaction mixture was cooled to room temperature. The sticky dark green solution was poured into a mixture of ice $(5.0 \mathrm{~g})$ and water $(5.0 \mathrm{~mL})$. The green precipitate was collected by filtration. The crude product was purified by flash column chromatography using $5 \%$ ethyl acetate/hexanes as eluent. The first fraction was the desired product as dark green crystals $(25 \mathrm{mg}, 25 \%)$, m.p. $>310^{\circ} \mathrm{C}$. IR (KBr, cm ${ }^{-1}: 2148$ $(\mathrm{C} \equiv \mathrm{C}, \mathrm{m})$. UV-vis (THF) (nm, relative intensity): 732 (2.16), 698 (2.03), $668(0.59), 636(0.48), 424(0.51)$, 372 (1.44), 314 (1.44), $258(0.85)$. ${ }^{1} \mathrm{H} \mathrm{NMR}\left(\mathrm{C}_{6} \mathrm{D}_{6}\right): \delta$ $9.79(\mathrm{~s}, 8 \mathrm{H}), 1.30(\mathrm{~s}, 72 \mathrm{H}), 0.51(\mathrm{~s}, 48 \mathrm{H})$. FAB-MS $\mathrm{m} / \mathrm{z}$, relative intensity): $1619\left(\mathrm{M}^{+}+1,50\right), 1273$ $\left(\mathrm{M}^{+}\right.$- 3(butyldimethylsilyl), 48), 735 (100). Anal. calc. for $\mathrm{C}_{96} \mathrm{H}_{130} \mathrm{~N}_{8} \mathrm{Si}_{8}: \mathrm{C}, 71.20 ; \mathrm{H}, 8.03 ; \mathrm{N}, 6.92$. Found: C, 71.21; H, 8.29; N, 6.71.

\section{$2,3,9,10,16,17,23,24-O c t a k i s(t e r t-$} butyldimethylsilylethynyl)phthalocyaninato zinc(II) (6)

Compound 3 (200 mg, $0.12 \mathrm{mmol}$ ) was dissolved in DMAE ( $2 \mathrm{~mL}$ ). As ammonia gas was bubbled through, the reaction mixture was heated to $100-110^{\circ} \mathrm{C}$ (sand bath) and kept for $1 \mathrm{~h}$. During this time the initial light orange color turned to dark orange. When heated to reflux, the color of the reaction mixture became green. After refluxing for $4 \mathrm{~h}$, the reaction mixture was cooled to $80^{\circ} \mathrm{C}$. The dark green solution was transferred to a $100 \mathrm{~mL}$ round-bottom flask. DMF 
$(20 \mathrm{~mL})$, toluene $(20 \mathrm{~mL})$ and dry zinc acetate (300 mg, $254 \mathrm{mmol}$ ) were added. The reaction mixture was refluxed for $12 \mathrm{~h}$. After the solvent was evaporated to half its volume, the concentrated solution was poured onto ice $(20 \mathrm{~g})$. A dark blue precipitate was collected and purified by flash column chromatography using $20 \%$ ethyl acetate/hexanes as eluent. Methanol $(10 \mathrm{~mL})$ was added to the desired fraction which had been concentrated ( $c a 10 \mathrm{~mL}$ ) to afford dark blue fine crystals $(50 \mathrm{mg}, 24 \%)$, m.p. $>310^{\circ} \mathrm{C}$. IR $\left(\mathrm{KBr}, \mathrm{cm}^{-1}: 2148(\mathrm{C}=\mathrm{C}, \mathrm{w})\right.$. UV-vis (THF) (nm, relative intensity): $710(0.64), 678(0.08), 638(0.09)$, $374(0.24) .{ }^{1} \mathrm{H}$ NMR $\left(\mathrm{C}_{6} \mathrm{D}_{6}\right): \delta 9.93(\mathrm{~s}, 8 \mathrm{H}) 1.29(\mathrm{~s}$, $72 \mathrm{H}), 0.50(\mathrm{~s}, 48 \mathrm{H})$. FAB-MS $m / 2$, relative intensity): $1682\left(\mathrm{M}^{+}, 100\right)$. Anal. calc. for $\mathrm{C}_{96} \mathrm{H}_{128} \mathrm{~N}_{8} \mathrm{Si}_{8} \mathrm{Zn}: \mathrm{C}$, $68.53 ; \mathrm{H}, 7.61 ; \mathrm{N}, 6.66$. Found: $\mathrm{C}, 68.96 ; \mathrm{H}, 7.86 ; \mathrm{N}$, 6.50 .

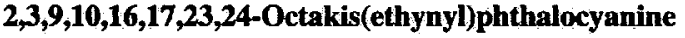 (7)}

Compound 5 ( $30 \mathrm{mg}, 0.019 \mathrm{mmol})$ was dissolved in THF ( $3 \mathrm{~mL})$. One drop of water and three drops of tetrabutylammonium fluoride (TBAF, 1.0 M solution in THF) were added. The dark green solution was stirred at room temperature for $72 \mathrm{~h}$. A dark blue precipitate was formed. Methanol $(2 \mathrm{~mL})$ was added to form more precipitate. The precipitate was filtrated, washed with methanol and water and dried under vacuum. A dark blue powder was obtained $(11 \mathrm{mg}$, $84 \%)$, m.p. $>310^{\circ} \mathrm{C}$. IR (KBr, cm $\left.{ }^{-1}\right): 3219(\mathrm{C} \equiv \mathrm{CH}$, s), $2106(\mathrm{C} \equiv \mathrm{C}, \mathrm{w})$. UV-vis (THF) (nm, relative intensity): $708(0.86), 636(0.26), 364(0.40), 261$ $(0.60)$.

\section{$2,3,9,10,16,17,23,24-$}

Octakis(ethynyl)phthalocyaninatozinc(II) (8)

Compound $6(20 \mathrm{mg}, 0.012 \mathrm{mmol})$ was dissolved in THF $(20 \mathrm{~mL})$. Two drops of water and TBAF $(1.0 \mathrm{~mL}$ of $1.0 \mathrm{M}$ solution in THF) were added. The dark blue solution was stirred under Ar for $40 \mathrm{~h}$. Ethyl acetate $(20 \mathrm{~mL})$ was added. The reaction solution was washed with water $(10 \mathrm{ml} \times 3)$, dried over $\mathrm{MgSO}_{4}$ and concentrated to half its volume. The crude product was purified by flash column chromatography using $40 \%$ ethyl acetate/hexanes and THF as eluents sequentially. A dark blue powder $(7.8 \mathrm{mg}, 85 \%)$ was obtained when methanol was added to the THF solution, m.p. $>310^{\circ} \mathrm{C}$. IR $\left(\mathrm{KBr}, \mathrm{cm}^{-1}\right)$ : 3285 $(\mathrm{C} \equiv \mathrm{CH}, \mathrm{s}), 2094$ (C三C, w). UV-vis (THF) (nm, relative intensity): $698(1.20), 664(0.26), 628(0.24)$,
$252(0.47), 366(0.54) .{ }^{1} \mathrm{H}$ NMR (pyridine- $d_{5}, 90^{\circ} \mathrm{C}$ ): $\delta$ $9.82(\mathrm{~s}, 8 \mathrm{H}), 4.47(\mathrm{~s}, 8 \mathrm{H})$.

\section{3-Bromophthalonitrile (10)}

3-Aminophthalonitrile (16) $(0.5 \mathrm{~g}, 3.49 \mathrm{mmol})$ [25] was mixed with $48 \%$ hydrobromic acid $(10 \mathrm{~mL})$ and ice $(24.7 \mathrm{~g})$, and a solution of sodium nitrite $(0.37 \mathrm{~g}$, $5.5 \mathrm{mmol})$ in water $(3.2 \mathrm{~mL})$ was added in one portion. The resulting mixture was stirred for $2 \mathrm{~h}$ in an ice bath. At the same time a solution of cuprous bromide was prepared by dissolving anhydrous cupric sulfate crystals $(1.0 \mathrm{~g}, 62.7 \mathrm{mmol})$ and potassium bromide $(0.5 \mathrm{~g}, 4.20 \mathrm{mmol})$ in hot water $\left(3 \mathrm{~mL}, 80^{\circ} \mathrm{C}\right)$. To the resulting mixture a solution of sodium metabisulfite $(0.2 \mathrm{~g}, 1.05 \mathrm{mmol})$ and sodium hydroxide $(0.1 \mathrm{~g}$, $2.50 \mathrm{mmol})$ in water $(1.6 \mathrm{~mL})$ was added and stirred for $0.5 \mathrm{~h}$ in an ice bath. The diazonium solution was poured rapidly into the cold cuprous bromide solution and allowed to warm to room temperature. Once the solutions were thoroughly mixed, $48 \%$ hydrobromic acid ( $1 \mathrm{~mL})$ was added. The resulting mixture was stirred for $2.3 \mathrm{~h}$. The mixture was extracted three times with ether and the extract was washed with water, a $1 \%$ solution of $\mathrm{NaHCO}_{3}$, a $1 \%$ solution of $\mathrm{NaHSO}_{3}$, water and dried over anhydrous $\mathrm{MgSO}_{4}$. After evaporation the mixture was separated by silica gel chromatography using benzene as eluent and recrystallized from benzene/hexane to give $10(0.35 \mathrm{~g}, 45 \%$ yield) as white crystals, m.p. $151-152^{\circ} \mathrm{C}$. IR $(\mathrm{KBr}$, $\left.\mathrm{cm}^{-1}\right): 2215(\mathrm{CN}){ }^{1} \mathrm{H}$ NMR $\left(\mathrm{CDCl}_{3}\right): \delta 7.97(1 \mathrm{H}, \mathrm{d}$, $J=8.0 \mathrm{~Hz}): 7.80(1 \mathrm{H}, \mathrm{d}, J=8.0 \mathrm{~Hz}): 7.61(1 \mathrm{H}, \mathrm{t}$, $J=8.0 \mathrm{~Hz})$. EI-MS $(\mathrm{m} / \mathrm{z}$, relative intensity): 206,208 $\left(\mathrm{M}^{+}, 100\right)$. Anal. calc. for $\mathrm{C}_{8} \mathrm{H}_{3} \mathrm{BrN}_{2}: \mathrm{C}, 46.41 ; \mathrm{H}$, $1.46 ; \mathrm{N}, 13.53$. Found: C, 46.34; H, 1.16; N, 13.54 .

\section{3,6-Dibromophthalonitrile (12), 3,4- Dibromophthalonitrile (13) and 4,5- Dibromophthalonitrile (14)}

A sample $(8.6 \mathrm{~g}, 30.0 \mathrm{mmol})$ of $N, N$-dibromoisocyanuric acid (DBI) [22] was dissolved in $50 \mathrm{~mL}$ of $8 \%$ fuming sulfuric acid at room temperature. Once dissolved, the solution was cooled in an ice bath and $6.9 \mathrm{~g}(54.0 \mathrm{mmol})$ of phthalonitrile (9) was added to the solution. The mixture was stirred in an ice bath for $5 \mathrm{~min}$ before being poured onto ice water. The resulting mixture was extracted three times with ether and the extract was washed with $\mathrm{H}_{2} \mathrm{O}$, a $1 \%$ solution of $\mathrm{NaHCO}_{3}$, a $1 \%$ solution of $\mathrm{NaHSO}_{3}$, water and dried over anhydrous $\mathrm{MgSO}_{4}$. Evaporation of the solvent gave a solid mixture which was separated by silica gel 
column chromatography using a gradient of ethyl acetate-hexane $(1: 19,1: 4,0: 1)$ as eluent to give traces of tri- and tetrabromophthalonitrile $(1.8 \%)$, a mixture of 9 and $10(13 \%)$, 4-bromophthalonitrile (45.2\%) [33], pure $12(7 \%)$, pure $13(5.9 \%)$ and pure $14(6.7 \%)$.

Compound 12, m.p. $250-252^{\circ} \mathrm{C}$. IR $\left(\mathrm{KBr}, \mathrm{cm}^{-1}\right)$ : $2225(\mathrm{CN}) .{ }^{1} \mathrm{H}$ NMR $\left(\mathrm{CDCl}_{3}\right): \delta 7.78(2 \mathrm{H}, \mathrm{s})$. EI-MS $\left(\mathrm{m} / \mathrm{z}\right.$, relative intensity): $286\left(\mathrm{M}^{+}, 100\right)$. Anal. calc. for $\mathrm{C}_{8} \mathrm{H}_{3} \mathrm{BrN}_{2}: \mathrm{C}, 33.60 ; \mathrm{H}, 0.71 ; \mathrm{N}, 9.80$. Found: $\mathrm{C}$, $33.57 ; \mathrm{H}, 0.67 ; \mathrm{N}, 9.60$.

Compound 13, m.p. $164-165^{\circ} \mathrm{C}$. IR $\left(\mathrm{KBr}, \mathrm{cm}^{-1}\right)$ : $2220(\mathrm{CN}) .{ }^{1} \mathrm{H}$ NMR $\left(\mathrm{CDCl}_{3}\right): \delta 8.01(1 \mathrm{H}, \mathrm{d}$, $J=8.7 \mathrm{~Hz}), 7.63(1 \mathrm{H}, \mathrm{d}, J=8.7 \mathrm{~Hz})$. El-MS $(\mathrm{m} / \mathrm{z}$, relative intensity): $286\left(\mathrm{M}^{+}, 80\right)$. Anal. calc. for $\mathrm{C}_{8} \mathrm{H}_{3} \mathrm{BrN}_{2}: \mathrm{C}, 33.60 ; \mathrm{H}, 0.71 ; \mathrm{N}, 9.80$. Found: $\mathrm{C}$, $33.50 ; \mathrm{H}, 0.61 ; \mathrm{N}, 9.73$.

Compound 14, m.p. $214-216^{\circ} \mathrm{C}$. IR $\left(\mathrm{KBr} \mathrm{cm}^{-1}\right)$ : $2215(\mathrm{CN}) .{ }^{1} \mathrm{H}$ NMR $\left(\mathrm{CDCl}_{3}\right): \delta 8.07(2 \mathrm{H}, \mathrm{s})$. EI-MS $\left(\mathrm{m} / \mathrm{z}\right.$, relative intensity): $286\left(\mathrm{M}^{+}, 100\right)$. Anal. calc. for $\mathrm{C}_{8} \mathrm{H}_{2} \mathrm{BrN}_{2}$ : C, 33.60; $\mathrm{H}, 0.71 ; \mathrm{N}, 9.80$. Found: $\mathrm{C}$, $33.71 ; \mathrm{H}, 0.51 ; \mathrm{N}, 9.85$.

\section{4,5-Dibromophthalimide (18a)}

To $60 \mathrm{~mL}$ of $30 \%$ fuming sulfuric acid were added $14.7 \mathrm{~g}(0.1 \mathrm{~mol})$ of phthalimide $(17), 32.0 \mathrm{~g}(0.2 \mathrm{~mol})$ of bromine and $0.1 \mathrm{~g}$ of iodine as catalyst. The reaction mixture was heated to $65-75^{\circ} \mathrm{C}$ for $24 \mathrm{~h}$ and then air was bubbled through the solution to remove unreacted bromine. This mixture was then poured onto $400 \mathrm{~g}$ of ice and the resulting suspension was extracted by ethyl acetate five times. The combined organic layers were washed twice with water, once with a $2 \%$ solution of $\mathrm{K}_{2} \mathrm{CO}_{3}$, a saturated solution of $\mathrm{Na}_{2} \mathrm{~S}_{2} \mathrm{O}_{3}$ and dried using $\mathrm{MgSO}_{4}$. The solvent was evaporated and the resulting solid was recrystallized from acetone to give $10.8 \mathrm{~g}$ of pure 18a. Water was added to the mother liquor to precipitate 18a. After heating and cooling the resulting mixture, another $7.7 \mathrm{~g}$ of pure $18 \mathrm{a}$ was isolated. This procedure was repeated two more times to give an additional $3.5 \mathrm{~g}$ of intermediate $18 \mathrm{a}$. The resulting solution contained mostly 4,5-dibromophthalic acid $18 \mathrm{~b}$ (m.p. $243-245^{\circ} \mathrm{C}$; lit. m.p. $242-244^{\circ} \mathrm{C}$ [27]). The overall yield of $18 \mathrm{a}$ was $72 \%$, m.p. 233 $234^{\circ} \mathrm{C}$. IR $\left(\mathrm{KBr}, \mathrm{cm}^{-1}\right): 3140(\mathrm{NH}), 1740(\mathrm{C}=\mathrm{O})$, $1710(\mathrm{C}=\mathrm{O}) .{ }^{1} \mathrm{H}$ NMR $\left(\mathrm{CDCl}_{3}\right) ; \delta 8.11(2 \mathrm{H}, \mathrm{s})$. EIMS ( $\mathrm{m} / \mathrm{z}$, relative intensity): $305\left(\mathrm{M}^{+}, 100\right)$.

\section{4,5-Dibromophthalamide (19)}

To $90 \mathrm{~mL}$ of conc. aqueous ammonia was added $9.2 \mathrm{~g}$ (30 mmol) of intermediate 4,5-dibromophthalimide (18a). The rapidly stirred mixture was heated to $50-$ $60^{\circ} \mathrm{C}$ for $1 \mathrm{~h}$. The white solid was filtered and washed three times with ice-cold water and with methanol to remove any trace amounts of ammonia and 18a. The solid was dried overnight at room temperature to give intermediate $19(7.8 \mathrm{~g}, 80 \%)$ as a white powder, m.p. 240-243 ${ }^{\circ} \mathrm{C}$. IR $\left(\mathrm{KBr}, \mathrm{cm}^{-1}\right)$ : [3380,3275,3120(NH)], 1670, $1630(\mathrm{C}=\mathrm{O}), 1580 .{ }^{1} \mathrm{H}$ NMR $\left(\mathrm{DMSO}-d_{6}\right.$, $27^{\circ} \mathrm{C}$ ): $\delta 7.90(\mathrm{~s}, 2 \mathrm{H}), 7.80,7.39(\mathrm{bs}, 4 \mathrm{H})$.

\section{4,5-Dibromophthalonitrile (14)}

To an ice-cooled stirred suspension of $5.6 \mathrm{~g}$ (17.4 mmol) of 19 in $150 \mathrm{~mL}$ of dry dioxane and $11.5 \mathrm{~mL}$ of dry pyridine was added $10.2 \mathrm{~mL}$ of trifluoracetic anhydride at $0-5^{\circ} \mathrm{C}$. After the addition was complete, the reaction mixture was warmed to room temperature, stirred overnight and poured onto ice. The product was extracted three times with EtOAc. The organic layer was washed with water, $1 \mathrm{M} \mathrm{HCl}$, dilute $\mathrm{Na}_{2} \mathrm{CO}_{3}$, water and dried over $\mathrm{MgSO}_{4}$. The solvent was removed under vacuum and the product was recrystallized from ethanol to give $14(4.2 \mathrm{~g}, 85 \%)$ as white needles, m.p. $214-216^{\circ} \mathrm{C}$, identical to that produced by direct bromination of 9 .

\section{3-Bromo-4-(3,3-dimethyl-1-butynyl)phthalonitrile (21) and 3,4-Bis(3,3-dimethyl-1- butynyl)phthalonitrile (22)}

To $10 \mathrm{~mL}$ of a triethylamine/DMF (1:1) solution containing $210 \mathrm{mg}(0.73 \mathrm{~mol})$ of 3,4-dibromophthalonitrile (13) were added $0.4 \mathrm{~mL}$ of 3,3 -dimethyl-1butyne (20), $100 \mathrm{mg}$ of cuprous iodide and $10 \mathrm{mg}$ of $\mathrm{Pd}\left[\mathrm{P}\left(\mathrm{Ph}_{3}\right)_{2}\right]_{2} \mathrm{Cl}_{2}$ as a catalyst. The mixture was stirred at room temperature under an argon atmosphere. After $18 \mathrm{~h}$ starting material disappeared and two products appeared as shown by a thin layer chromatogram. Although an additional three portions of 3,3-dimethyl1-butyne, cuprous iodide and $\mathrm{Pd}$ (II) catalyst were added to the reaction mixture every $8 h$, the reaction did not proceed further. The reaction mixture was filtered to remove insoluble solids and the solids were washed with ethyl ether. The filtrate and the washes were combined and the solvent was evaporated under reduced pressure to give $70 \mathrm{mg}$ of dark brown solids. The mixture was preabsorbed on silica gel and chromatographed over silica gel using hexane/ethyl acetate (19:1) as eluent to give, in the first fractions, in $40 \%$ yield, $85 \mathrm{mg}$ of 3,4-di(3,3-dimethyl-1-butynyl)phthalonitrile (22) as white crystals, m.p. 147$149^{\circ} \mathrm{C}$. IR $\left(\mathrm{KBr}, \mathrm{cm}^{-1}\right): 2235(\mathrm{CN}) .{ }^{1} \mathrm{H}$ NMR 
(DMSO- $\left.d_{6}\right): \delta 8.00(\mathrm{~d}, 1 \mathrm{H}, J=8 \mathrm{~Hz}), 7.85(\mathrm{~d}, 1 \mathrm{H}$, $J=8 \mathrm{~Hz}), 1.36(\mathrm{~s}, 9 \mathrm{H}), 1.34(\mathrm{~s}, 9 \mathrm{H})$. MS $(\mathrm{m} / \mathrm{z}$, relative intensity): $288\left(\mathrm{M}^{+}, 80\right)$. Anal. calc. for $\mathrm{C}_{20} \mathrm{H}_{20} \mathrm{~N}_{2}$ : C, 83.28; H, 7.00; $\mathrm{N}, 9.71$. Found: $\mathrm{C}, 83.11 ; \mathrm{H}, 7.14 ; \mathrm{N}$ 9.69 .

Further elution gave $95 \mathrm{mg}$ of 3-bromo-4-(3,3dimethyl-1-butynyl)phthalonitrile (21) in $45 \%$ yield, m.p. $139-140^{\circ} \mathrm{C}$. IR $\left(\mathrm{KBr}, \mathrm{cm}^{-1}\right): 2230(\mathrm{CN}) .{ }^{1} \mathrm{H}$ NMR (DMSO- $\left.d_{6}\right): \delta 8.10(\mathrm{~d}, 1 \mathrm{H}, J=8 \mathrm{~Hz}), 7.92(\mathrm{~d}$, $1 \mathrm{H}, J=8 \mathrm{~Hz}), 1.35(\mathrm{~s}, 9 \mathrm{H})$. MS ( $\mathrm{m} / \mathrm{z}$, relative intensity): 286, $288\left(\mathrm{M}^{+}, 100\right)$. Anal. calc. for $\mathrm{C}_{14} \mathrm{H}_{11} \mathrm{~N}_{2} \mathrm{Br}$ : C, 58.15; $\mathrm{H}, 3.83 ; \mathrm{N}, 9.69$. Found: $\mathrm{C}$, $58.65 ; \mathrm{H}, 3.74 ; \mathrm{N}, 9.70$.

\section{1,2,8,9,15,16,22,23-Octakis(3,3-dimethyl-1- butynyl)phthalocyanine (23)}

To $2.5 \mathrm{~mL}$ of 1-pentanol was added $30 \mathrm{mg}$ of lithium metal and the solution was stirred under argon at $60^{\circ} \mathrm{C}$. After all the lithium metal had dissolved, the solution was cooled to room temperature. To an aliquot of $0.5 \mathrm{~mL}$ of this solution, $50 \mathrm{mg}$ of 22 was added. The reaction mixture was then heated to $110^{\circ} \mathrm{C}$ under argon. The reaction was monitored by TLC with benzene as eluent. After $3 \mathrm{~h}$, all the starting phthalonitrile (22) was gone; the reaction was then cooled to room temperature and diluted with $10 \mathrm{~mL}$ of $20 \%$ methanol/water. After $90 \mathrm{~min}$ the reaction mixture was centrifuged and the precipitate was collected. The precipitate was further washed with methanol and collected by centrifugation. This process was continued until the filtrate was colorless. At this point the crude pigment was further purified by flash column chromatography using benzene as eluent. The first band collected was the desired Pc 23 and was further purified by a second fiash silica gel column to remove all insoluble impurities. Final purification involved the reprecipitation of 23 from THF/ethanol, which gave the desired $\mathrm{Pc}$ in $35 \%$ yield. ${ }^{1} \mathrm{H}$ NMR (nitrobenzene$\left.\mathrm{d}_{5}, 2.44 \times 10^{-3} \mathrm{M}, 117^{\circ} \mathrm{C}\right): \delta 9.70(\mathrm{~d}, J=7 \mathrm{~Hz}, 4 \mathrm{H})$, $8.45(\mathrm{~d}, J=7 \mathrm{~Hz}, 4 \mathrm{H}), 1.79(\mathrm{~s}, 36 \mathrm{H}), 1.72(\mathrm{~s}, 36 \mathrm{H})$, -0.16 (br, 2H). UV-vis $\left(\mathrm{CHCl}_{3}\right): \lambda_{\max }(\mathrm{nm})(\log \varepsilon)$ 734 (5.32), 698 (5.27), 666 (4.72), 632 (4.59), 418 (4.65), 368 (5.03), $314(4.89)$. FAB-MS $(\mathrm{m} / \mathrm{z}): 1154$ $(\mathrm{M}+1)$. Anal. calc. for $\mathrm{C}_{80} \mathrm{H}_{82} \mathrm{~N}_{8}: \mathrm{C}, 83.15 ; \mathrm{H}, 7.15$; $\mathrm{N}, 9.70$. Found: $\mathrm{C}, 83.10 ; \mathrm{H}, 6.79 ; \mathrm{N}, 9.09$.

\section{Acknowledgements}

The authors wish to thank the Natural Sciences and Engineering Research Council for support for this research.

\section{REFERENCES}

1. C. C. Leznoff, in Phthalocyanines: Properties and Applications, Vol. 1 eds C. C. Leznoff and A. B. P. Lever), VCH Publishers, New York, pp. 1-54 (1989).

2. F. H. Moser and A. L. Thomas, The Phthalocyanines, Vols 1 and 2, CRC Press, Boca Raton, FL (1983).

3. A. W. Snow and W. R. Barger, in Phthalocyanines: Properties and Applications, Vol. 1 (eds C. C. Leznoff and A. B. P. Lever), VCH Publishers, New York, pp. 341-392 (1989).

4. H. S. Nalwa and J. S. Shirk, Phthalocyanines: Properties and Applications, Vol. 4 (eds C. C. Leznoff and A. B. P. Lever), VCH Publishers, New York, pp. 79-181 (1996).

5. J. J. Dougherty, Photochem. Photobiol. 58, 895 (1993).

6. R. Boyle and D. Dolphin, Photochem. Photobiol. 65, 469 (1996).

7. K. Kondo, S. Yasuda, T. Sakaguchi and M. Miya, $J$. Chem. Soc., Chem. Commun. 55 (1995).

8. O. Mongin, C. Papamicaël, N. Hoyler and A. Gossauer, J. Org. Chem. 63, 5568 (1998).

9. J. S. Lindsey, New J. Chem. 15, 153 (1991).

10. D. S. Terekhov, K. J. M. Nolan, C. R. McArthur and C. C. Leznoff, J. Org. Chem. 61, 3034 (1996).

11. K. J. M. Nolan and C. C. Leznoff, Synlett. 593 (1997).

12. H. Isago, D. S. Terekhov and C. C. Leznoff, $J$. Parphyrins Phthalocyanines 1, 135 (1997).

13. S. Vigh, H. Lam, P. Janda, A. B. P. Lever and C. C. Leznoff, Can. J. Chem. 69, 1457 (1991).

14. H. Naarmann and M. Hanack, Chem. Abstr. 115, P208923d (1991).

15. E. M. Maya, P. Haisch, P. Vázquez and T. Torres, Tetrahedron 54, 4397 (1998).

16. S. Sonogashira, Y. Tohda and D. J. Burton, J. Org. Chem. 58, 7368 (1993).

17. S. Takahashi, Y. Kuroyama, K. Sonogashira and N. Hagihara, Synthesis, 627 (1980).

18. K. Sonogashira, Y. Tohda and N. Hagihara, Tetrahedron Lett. 4467 (1975).

19. P. J. Brach, S. J. Grammatica, O. A. Ossanna and L. Weinberger, J. Heterocyclic Chem. 7, 1403 (1970).

20. J. R. Johnson and C. G. Gauerke, Organic Synthesis, Coll. Vol. 1 (eds H. Gilman and A. H. Blatt), Wiley, New York, p. 123 (1941).

21. F. L. Lambert, W. D. Ellis and R. J. Parry, J. Org. Chem. 30, 304 (1964).

22. W. Gottardi, Monatsh. Chem. 99, 815 (1968).

23. M. J. Cook, M. F. Daniel, K. J. Harrison, N. B. Mckeown and A. J. Thomson, J. Chem. Soc., Chem. Commun. 1086 (1987).

24. M. J. Cook, M. F. Daniel, K. J. Harrison, N. B. McKeown and A. J. Thomson, J. Chem. Soc., Chem. Commun. 1148 (1987).

25. C. C. Leznoff, D. S. Terekhov, C. R. McArthur, S. Vigh and J. Li, Can. J. Chem. 73, 435 (1995). 